\title{
PERBEDAAN ASUPAN PROTEIN, ZAT BESI, ASAM FOLAT, DAN VITAMIN B 12 ANTARA IBU HAMIL TRIMESTER III ANEMIA DAN TIDAK ANEMIA DI PUSKESMAS TANGGUNGHARJO KABUPATEN GROBOGAN
}

\author{
Ba'ul Setyawati, Ahmad Syauqy ${ }^{*}$ \\ Program Studi Ilmu Gizi Fakultas Kedokteran Universitas Diponegoro \\ J1.Dr.Sutomo No.18, Semarang, Telp (024) 8453708, Email : gizifk@ undip.ac.id
}

\begin{abstract}
Backgrounds: Iron Deficiency Anemia in pregnant women could be caused by insufficient intake and inadequate absorbtion of iron since in pregnancy women there's a increasing need of iron for hemoglobin production. Pregnant women tend to get anaemia in the $3^{\text {rd }}$ trimester because of increasing blood circulation to placenta and iron storage for the first month after birth. This study was conducted to figure out the difference of protein, iron, folic acid, and $B_{12}$ intake in anemia and non-anemia $3^{\text {rd }}$ trimester pregnant women in Tanggungharjo Grobogan.

Methods: This study is an observational study with cross sectional design which was conducted in Tanggungharjo Grobogan. There were 46 people aged 20-35 years old pregnant women in $3^{\text {rd }}$ trimester in which 23 subjects were anemic and 23 subjects were non-anemic. Subjects were chosen with consecutive sampling method. Hemoglobin measurement was conducted with Cyanmethemoglobin method by the experts. Protein, iron, folic acid and $B_{12}$ data were measured by Semiquantitative Food Frequency Questionnaire. Protein, iron, and vitamine $B_{12}$ were analyzed by MannWhitney test. Folic acid data were analyzed by Independent T-Test.

Results: Median (minimum-maximum) value of protein intake in subjects are 37,4 (29,4-67,8) g/day in aenemic group and 43,7 (29,4-67,8) g/day in non-aenemic group. Median (minimum-maximum value of iron intake are 6,9 (3,5-48) mg/day in aenemic group and 7,00 (3,7-11,8) mg/day in non-aenemic group. Median (minimum-maximum) value of $B_{12}$ are $1,1(0,5-3,5) \mu \mathrm{g} /$ day in aenemic group and $1,9(0,8-3,7)$ in non-aenemic group. Mean value of folic acid intake are 4,9 $\mu \mathrm{g} /$ day with deviation standard $6,52 \mathrm{~g}$ in aenemic group and 6,06 $\mu \mathrm{g} /$ day with deviation standard 7,11 $\mathrm{g}$ in non-aenemic group.

Conclussions: There's a significant difference of protein intake $(p=0.032)$ and vitamine $B_{12}(p=0.03)$, but there's no difference of iron $(p=0.75)$ and folic acid $(p=0.56)$ intake between anemia and non-anemia $3^{\text {rd }}$ trimester pregnant women in Tanggungharjo, Grobogan. The occurence of aenemia in subjects could be caused by defficiency of vitamine $B_{12}$ intake which is called as megaloblastic aenemia.
\end{abstract}

Keywords: protein intake; iron intake; folic acid intake; vitamine $B_{12}$ intake; hemoglobin level; $3^{\text {rd }}$ trimester pregnant women

ABSTRAK

Latar Belakang: Ibu hamil cenderung terkena anemia pada trimester III dikarenakan perubahan sirkulasi yang makin meningkat terhadap plasenta serta pada masa trimester III janin menimbun cadangan zat besi untuk dirinya sebagai persediaan bulan pertama sesudah kelahiran sehingga kebutuhan akan zat gizi ibu juga meningkat. Penelitian bertujuan untuk mengetahui perbedaan asupan protein, zat besi, asam folat dan vitamin $B_{12}$ pada ibu hamil anemia dan tidak anemia trimester III di puskesmas Tanggungharjo Kabupaten Grobogan.

Metode: Penelitian observasional dengan rancangan cross-sectional bertempat di wilayah di puskesmas Tanggungharjo Kabupaten Grobogan. Sampel berjumlah 46 subyek yang merupakan ibu hamil trimester III dimana 23 ibu hamil anemia dan 23 ibu hamil tidak anemia yang berusia 20-35 tahun dan dipilih menggunakan metode consecutive sampling. Pengukuran Hb menggunakan metode Cyanmethemoglobin yang dilakukan oleh tenaga ahli. Asupan protein , zat besi $(\mathrm{Fe})$, asam folat dan vitamin $B_{12}$ diukur dengan menggunakan Semiquantitative Food Frequency Questionnair. Data asupan protein, zat besi dan vitamin $B_{12}$ dianalisis menggunakan uji Mann Whitney dan asupan asam folat dianalisis menggunakan Independent T-Test..

Hasil: Pada penelitian ini didapatkan nilai median (minimum-maksimum) untuk asupan protein adalah 37,4 (29,467,8) gr/hari dari kelompok anemia dan 43,7 (29,4-67,8) gr/hari dari kelompok tidak anemia, untuk asupan zat besi adalah 6,9 (3,5-48,0) mg/hari dari kelompok anemia dan 7,00 (3,7-11,8) mg/hari dari kelompok anemia, serta untuk asupan vitamin $B_{12}$ adalah 1,1 (0,5-3,5) $\mu$ g/hari dari kelompok anemia dan 1,9 (0,8-3,7) $\mu$ g/hari dari kelompok tidak anemia. Nilai rerata asupan asam folat pada kelompok anemia adalah 4,9 $\mu$ g/hari dan Standar Deviasi (SD) 6,52 gr, sedangkan pada kelompok tidak anemia adalah 6,06 $\mu \mathrm{g} /$ hari dan Standar Deviasi (SD) 7,11 gr.

Simpulan: Terdapat perbedaan bermakna asupan protein $(p 0,032)$ dan vitamin $B_{12}(p 0,03)$ antara ibu hamil trimester III anemia dan tidak anemia serta tidak terdapat perbedaan bermakna asupan zat besi $(p=0,75)$ dan asam folat $(p=0,56)$ antara ibu hamil trimester III anemia dan tidak anemia di Puskesmas Tanggungharjo Kabupaten

${ }^{*}$ Penulis Penanggungjawab 
Grobogan. Pada penelitian ini dari hasil analisis data asupan yang telah dilakukan, kejadian anemia pada ibu hamil trimester III disebabkan defisiensi vitamin $B_{12}$ yang sering disebut anemia megaloblastik

Kata kunci : asupan protein; asupan zat besi; asupan asam folat ; asupan vitamin $B_{12}$; kadar Hb; ibu hamil trimester III

\section{PENDAHULUAN}

Ibu hamil merupakan salah satu kelompok dalam masyarakat yang paling mudah menderita gangguan kesehatan karena kekurangan gizi, hal ini ditandai dengan masih tingginya Angka Kematian Ibu (AKI) pada tahun 2012 di Jawa Tengah sebanyak sebanyak 675 kasus dari 604 ribu ibu hamil yang disebabkan oleh Kekurangan Energi Kronis dan anemia. ${ }^{1}$

Anemia merupakan masalah yang sering terjadi pada kelompok dewasa yaitu wanita usia subur (WUS) terutama wanita hamil. Berdasarkan data World Health Organization (WHO) pada tahun 2008, prevalensi anemia ibu hamil di negara berkembang meningkat dari $35 \%$ menjadi $75 \%$. Prevalensi anemia wanita hamil di Asia pada tahun 2008 diperkirakan sebesar 48,2 \%. ${ }^{2}$ Hasil survey anemia ibu hamil pada tahun 2010 di 15 kabupaten/kota di Jawa Tengah sebesar 78,6\%. Angka prevalensi ini masih lebih tinggi dibandingkan dengan angka Nasional sebesar $71,6 \%$. Prevalensi anemia di Puskesmas Tanggungharjo di Kabupaten Grobogan pada tahun 2011 sebesar $11 \%{ }^{1}$

Prevalensi anemia meningkat pada kehamilan dari trimester II ke trimester III sebesar 2,3 kali. Data penelitian di Turki menunjukkan bahwa terjadi peningkatan prevalensi anemia dari trimester II ke trimester III dari 21,2\% menjadi $37,5 \%{ }^{3}$ Ibu hamil trimester III dikatakan anemia jika kadar $\mathrm{Hb}<11 \mathrm{gr} / \mathrm{dL} .{ }^{4}$ Ibu hamil trimester III mengalami perubahan sirkulasi yang makin meningkat terhadap plasenta sehingga diperlukan tambahan asupan zat gizi. ${ }^{5}$

Status gizi ibu yang diukur melalui LILA mencerminkan cadangan zat gizi dan status gizi ibu dimasa pra hamil. Kekurangan gizi sebelum masa kehamilan akan berpengaruh terhadap status gizi ibu selama mengandung yang mengakibatkan kebutuhan gizi ibu hamil KEK lebih tinggi dibandingkan ibu yang tidak KEK karena untuk memenuhi kebutuhan ibu dan janinnya. ${ }^{6}$

Pada umumnya penduduk Indonesia terutama wanita hamil mengkonsumsi energi dibawah AKG serta mengkonsumsi sumber zat besi yang berasal dari protein nabati yang memiliki daya serap rendah dibandingkan dengan protein hewani. ${ }^{7}$ Hasil penelitian Eko, dkk (2012) menunjukkan pola makan ibu hamil trisemester III rata-rata $(65 \%)$ tidak sehat. ${ }^{8}$ Hasil yang sama juga didapatkan dari hasil penelitian Fatimah, dkk (2011) di Kabupaten Maros ditemukan anemia gizi sebesar 79,4 \% dengan jumlah asupan protein, vitamin $\mathrm{C}$, vitamin B6, zat besi dan zink juga dibawah $\mathrm{AKG}^{9}$

Anemia adalah suatu keadaan penurunan kadar hemoglobin $(\mathrm{Hb})$, hematokrit dan jumlah eritrosit dibawah nilai normal. Anemia yang sering terjadi di negara berkembang (developing countries) dan pada kelompok sosial ekonomi menengah kebawah adalah anemia gizi. Anemia gizi disebabkan oleh kekurangan zat gizi yang berperan dalam pembentukan hemoglobin, baik karena kekurangan konsumsi atau karena gangguan absorpsi. Zat gizi yang bersangkutan adalah protein, besi, piridoksin (vitamin $\mathrm{B}_{6}$ ), vitamin $\mathrm{B}_{12}$, vitamin $\mathrm{C}$, asam folat, dan vitamin E. ${ }^{10}$

Protein, besi, dan piridoksin (vitamin $\mathrm{B}_{6}$ ) berperan sebagai katalisator dalam sintesis hem. Protein berperan dalam pengangkutan besi ke sumsum tulang untuk membentuk molekul hemoglobin yang baru. Absorpsi dan pelepasan besi dari transferin ke dalam jaringan tubuh dipengaruhi oleh vitamin $\mathrm{C}$. Asam folat berperan dalam metabolisme asam amino yang diperlukan dalam pembentukan sel darah merah dan sel darah putih dan pematangannya. Vit B12 dibutuhkan untuk mengaktifkan asam folat, dan dalam fungsi normal metabolisme semua sel, terutama sel-sel saluran cerna, sumsum tulang dan jaringan syaraf. Stabilitas membran sel darah merah dipengaruhi oleh vitamin $\mathrm{E}^{10}$

Dampak dari masalah anemia pada masa kehamilan adalah meningkatkan risiko kematian janin selama periode prenatal, bayi lahir sebelum waktunya, meningkatkan risiko perdarahan postpartum, memicu hipertensi dan gagal jantung saat kehamilan, atau Berat Badan Lahir Rendah (BBLR). Secara keseluruhan 20-40 \% dari 50.000 kematian maternal juga disebabkan anemia saat kehamilan. ${ }^{11,12,13}$

Saat ini Pemerintah sedang menggalakan Scaling Up Nutrition Movement (SUN Movement). SUN Movement adalah suatu gerakan WHO yang bertujuan menurunkan masalah gizi, dengan status pada 1000 hari pertama kehidupan yaitu fase 270 hari selama kehamilan dan 730 hari kelahiran (sampai usia 2 tahun). ${ }^{14}$ Status gizi ibu hamil sebelum dan selama hamil sangat mempengaruhi 
pertumbuhan janin yang sedang dikandung. Apabila status gizi ibu normal pada masa sebelum dan selama hamil, maka status gizi anak yang dilahirkan juga baik. $^{6}$

Pola pemberian suplementasi zat besi di Puskesmas Tanggungharjo yaitu TTD diberikan dalam jumlah sebanyak 90 tablet yang didapatkan dari posyandu atau polindes. Kepatuhan ibu hamil dalam mengkonsumsi TTD masih kurang, sehingga masih ditemukan tingginya angka anemia di daerah tersebut.

Berdasarkan paparan diatas, peneliti tertarik untuk mengkaji perbedaan asupan protein dan zat gizi mikro pada ibu hamil trimester III. Penelitian ini diharapkan dapat memberikan informasi dan pengetahuan mengenai pentingnya asupan protein, zat besi, asam folat dan vitamin $\mathrm{B}_{12}$ untuk ibu hamil trimester III terhadap kejadian anemia serta dapat dijadikan pertimbangan dalam pengambilan kebijakan mengenai program penanganan anemia pada ibu hamil.

\section{METODE PENELITIAN}

Penelitian ini dilakukan pada ibu hamil trimester III di wilayah kerja Puksesmas Tanggungharjo Kabupaten Grobogan. Waktu pelaksanaan penelitian ini adalah bulan Oktober 2013. Penelitian ini termasuk lingkup gizi masyarakat dengan desain cross sectional.

Skrining dilakukan pada 52 orang ibu hamil trimester III dan didapatkan sebanyak 23 orang subyek mengalami anemia dan 29 subyek tidak anemia. Dari 29 ibu hamil tidak anemia, diambil 23 orang yang memenuhi syarat inklusi secara consecutive sampling sehingga diperoleh 46 subyek (23 orang subyek anemia dan 23 orang subyek tidak anemia).

Kriteria inklusi penelitian ini adalah ibu hamil berusia 20-35 tahun yang terdaftar di Puskesmas Tanggungharjo dengan usia kehamilan minimal 27 minggu, tidak menderita infeksi (influenza, demam, diare) satu bulan terakhir sebelum dilaksanakan penelitian. Kriteria eksklusi penelitian adalah ibu hamil mengundurkan diri sebagai sampel penelitian.

Variabel independen dalam penelitian ini adalah asupan protein, zat besi, asam folat, dan vitamin $\mathrm{B}_{12}$. Variabel dependen dalam penelitian ini adalah kejadian anemia pada ibu hamil. Data yang dikumpulkan dalam penelitian ini adalah identitas (usia, pendidikan terakhir, dan pendapatan), kadar hemoglobin, LILA, serta asupan protein, zat besi, dan asam folat ibu hamil. Usia kehamilan ibu hamil diketahui dari Buku
Kesehatan Ibu dan Anak (BKIA) yang terdaftar di Posyandu yang dinyatakan dalam minggu.

Kejadian anemia pada ibu hamil didefinisikan sebagai suatu keadaan dimana kadar hemoglobin $(\mathrm{Hb})$ di dalam darah ibu hamil trimester III lebih rendah dari nilai normal yang diukur menggunakan metode Cyanmethemoglobin. Pengambilan darah dilakukan oleh tenaga ahli dengan cara mengumpulkan ibu hamil trimester III di Balai Desa kemudian dianalisis oleh Laboratorium Telaga Medika di Kabupaten Grobogan. Hasilnya dikategorikan menjadi anemia $(\mathrm{Hb}<11 \mathrm{mg} / \mathrm{dL})$ dan normal $(\mathrm{Hb} \geq 11 \mathrm{mg} / \mathrm{dL}){ }^{4}$ Pengukuran LILA dilakukan untuk mendeteksi ibu hamil mengalami KEK apabila LILA $<23,5 \mathrm{~cm}$.

Asupan protein, zat besi, asam folat, dan vitamin $B_{12}$ ibu hamil didefinisikan sebagai jumlah asupan protein (gram), asupan zat besi (mg) serta asam folat dan vitamin $\mathrm{B}_{12}$ (mikrogram) yang berasal dari makanan dan minuman yang dikonsumsi sehari-hari dan diukur dengan menggunakan Semiquantitative Food Frequency Questionnaire. Data asupan protein, zat besi, asam folat, dan vitamin $B_{12}$ diambil setiap satu minggu sekali dan diperoleh dalam ukuran rumah tangga kemudian dihitung menggunakan nutrisoft. Asupan protein, zat besi, asam folat, dan vitamin $B_{12}$ dibandingkan dengan AKG ibu hamil.

Data yang diperoleh kemudian dianalisis menggunakan program komputer. Analisis univariat dilakukan untuk mendeskripsikan variabel asupan protein, zat besi, asam folat, dan vitamin $B_{12}$. Analisis bivariat dengan uji MannWithney untuk menganalisis perbedaan asupan protein, zat besi, dan vitamin $\mathrm{B}_{12}$ serta Independent T-Test untuk menganalisis perbedaan asupan asam folat antara ibu hamil trimester III anemia dan tidak anemia.

\section{HASIL PENELITIAN \\ Karakteristik Ibu Hamil}

Karakteristik ibu hamil dilihat pada Tabel 1. Pada penelitian ini didapatkan data ibu hamil tidak anemia yang memiliki LILA $\geq 23,5 \mathrm{~cm}$ sebanyak 16 orang $(69,6 \%)$ dari kelompok tidak anemia. Usia ibu hamil yang menjadi sampel penelitian didominasi usia 20-25 pada kelompok ibu hamil anemia $(56,5 \%)$ dan usia $26-30$ pada kelompok ibu hamil tidak anemia (52,5\%). Mayoritas pendidikan terakhir pada ibu hamil anemia adalah SMP (43,5\%), sedangkan pada kelompok tidak anemia $30,4 \%$ subyek memiliki pendidikan terakhir SMA. Sebanyak 73,9\% ibu 
hamil anemia memiliki pendapatan di bawah UMR tidak anemia memiliki pendapatan di atas UMR $(<\mathrm{Rp} 1.000 .000,-)$, sedangkan $52,2 \%$ ibu hamil

(>Rp 1.000.000,-).

Tabel 1. Karakteristik subyek

\begin{tabular}{|c|c|c|c|c|c|}
\hline \multirow{2}{*}{\multicolumn{2}{|c|}{ Karakteristik Subyek }} & \multicolumn{2}{|c|}{ Anemia } & \multicolumn{2}{|c|}{$\begin{array}{c}\text { Tidak } \\
\text { Anemia }\end{array}$} \\
\hline & & $\mathrm{N}$ & $\%$ & $\mathrm{n}$ & $\%$ \\
\hline \multicolumn{6}{|c|}{ LILA } \\
\hline & $<23,5 \mathrm{~cm}$ & 11 & 47,8 & 7 & 30,4 \\
\hline - & $\geq 23,5 \mathrm{~cm}$ & 12 & 52,2 & 16 & 69,6 \\
\hline \multicolumn{6}{|l|}{ Usia } \\
\hline & $20-25$ th & 13 & 56,5 & 7 & 30,4 \\
\hline & $26-30$ th & 7 & 30,4 & 12 & 52,5 \\
\hline - & $31-35$ th & 3 & 13,0 & 4 & 17,4 \\
\hline \multicolumn{6}{|c|}{ Pendidikan } \\
\hline - & SD & 3 & 13 & 6 & 26,1 \\
\hline - & SMP & 10 & 43,5 & 5 & 21,7 \\
\hline - & SMA & 9 & 39,1 & 7 & 30,4 \\
\hline- & $\begin{array}{l}\text { Perguruan } \\
\text { Tinggi }\end{array}$ & 1 & 4,3 & 5 & 21,7 \\
\hline \multicolumn{6}{|c|}{ Pendapatan } \\
\hline & $<1.000 .000$ & 17 & 73,9 & 11 & 47,8 \\
\hline- & $>1.000 .000$ & 6 & 26,1 & 12 & 52,2 \\
\hline
\end{tabular}

\section{Asupan Protein, Zat Besi dan Asam Folat}

Tabel 2. Asupan Protein, zat besi dan asam folat

\begin{tabular}{cccc}
\hline Asupan & Anemia & Tidak Anemia & p \\
\hline Protein & $37,4(25,6-79,6)$ & $43,7(29,4-67,8)$ & 0,032 \\
& ${ }_{a}^{a}$ & \\
Zat Besi & $6,9(3,5-48,0)^{a}$ & $7,00(3,7-11,8)^{a}$ & 0,75 \\
Asam Folat & $4,9 \pm 6,52^{\mathrm{b}}$ & $6,06 \pm 7,11^{\mathrm{b}}$ & 0,56 \\
Vit. B $_{\mathbf{1 2}}$ & $1,1(0,5-3,5)^{\mathrm{a}}$ & $1,9(0,8-3,7)^{\mathrm{a}}$ & 0,03 \\
\hline
\end{tabular}

${ }^{\mathrm{a}}=$ nilai median (maximum-minimum)

${ }^{\mathrm{b}}=$ nilai rerata $\pm \mathrm{SD}$

Tabel 2 menunjukkan rerata dan median asupan protein, zat besi, asam folat, dan vitamin $\mathrm{B}_{12}$ dari 46 responden. Asupan protein dari kelompok anemia yang berada dalam kategori cukup sebanyak 3 responden $(13,04 \%)$ dan dari kelompok tidak anemia yang berada dalam kategori cukup sebanyak 3 responden $(13,04 \%)$. Asupan zat besi dari kelompok anemia yang berada dalam kategori cukup hanya sebanyak 1 responden $(0,04 \%)$ dan dari kelompok tidak anemia seluruh responden berada dalam kategori kurang. Untuk asupan asam folat baik dari kelompok anemia dan tidak anemia seluruh subyek berada dalam kategori kurang. Untuk asupan vitamin $\mathrm{B}_{12}$ dari kelompok anemia yang berada dalam kategori cukup sebanyak 5 responden $(21,73$
\%) dan dari kelompok tidak anemia sebanyak 7 responden $(30,43 \%)$.

Melalui Uji Mann-Withney dapat disimpulkan bahwa terdapat perbedaan asupan protein $(p=0,032)$ dan vitamin $\mathrm{B}_{12}(p=0,03)$ antara ibu hamil trimester III anemia dan tidak anemia serta tidak terdapat perbedaan asupan zat besi antara ibu hamil trimester III anemia dan tidak anemia $(p=0,75)$. Melalui independent T-Test dapat disimpulkan bahwa tidak terdapat perbedaan asupan asam folat antara ibu hamil trimester III anemia dan tidak anemia $(p=0,56)$.

\section{PEMBAHASAN}

Berdasarkan aspek sosial ekonomi yang dinilai berdasarkan tingkat pendidikan dan pendapatan, diketahui bahwa mayoritas ibu hamil 
trimester III dari kelompok anemia memiliki pendidikan terakhir SMP dengan pendapatan kurang dari UMR (< Rp 1.000.000,-). Pengetahuan gizi merupakan landasan penting yang mempengaruhi sikap dan perilaku gizi. Tingkat pendidikan juga berhubungan dengan status gizi karena dengan meningkatnya pendidikan kemungkinan akan meningkatkan pengetahuan dan pendapatan sehingga meningkatkan daya beli makanan. Tingkat ekonomi (pendapatan) yang rendah dapat mempengaruhi pola makan. Pada tingkat pendapatan yang rendah, sebagian besar pengeluaran ditujukan untuk memenuhi kebutuhan pangan dengan berorientasi pada jenis pangan karbohidrat. ${ }^{15,16,17,18}$ Hal ini disebabkan makanan yang mengandung banyak karbohidrat lebih murah dibandingkan dengan makanan sumber protein, zat besi, asam folat, dan vitamin $B_{12}$ sehingga kebutuhannya lebih sulit terpenuhi dan dapat berdampak pada terjadinya anemia gizi. ${ }^{7}$

Protein merupakan salah satu unsur zat gizi yang perlu diperhatikan pada kondisi kehamilan. Ibu hamil membutuhkan protein lebih banyak dibandingkan dengan kondisi biasanya untuk menunjang pembentukan sel-sel bagi ibu dan bayi. Protein diketahui berperan dalam transport zat besi dalam bentuk transferin. ${ }^{5}$

Pada penelitian ini menunjukkan terdapat perbedaan rerata asupan protein antara ibu hamil trimester III anemia dan tidak anemia $(p=0,032)$. Hasil penelitian ini sama dengan pada penelitian sebelumya yang dilakukan di Turki bahwa terdapat perbedaan rerata asupan protein ibu hamil anemia dan tidak anemia. ${ }^{3}$ Pada penelitian ini didapatkan data bahwa ibu hamil tidak anemia lebih sering mengkonsumsi protein hewani dengan frekuensi 45 kali seminggu sedangkan ibu hamil anemia frekuensi konsumsi sebanyak 3-4 kali seminggu. Konsumsi protein nabati pada ibu hamil anemia lebih tinggi dengan frekuensi sebanyak 6-7 kali seminggu dibanding ibu hamil tidak anemia dengan frekuensi sebanyak 3-5 kali seminggu.

Hal ini sejalan dengan teori bahwa mutu protein ditentukan oleh jenis dan proporsi asam amino yang dikandungnya. Protein komplet atau dengan nilai biologi tinggi adalah protein yang mengandung semua jenis asam amino esensial dalam proporsi yang sesuai untuk pertumbuhan. Sumber dari protein komplet adalah semua protein hewani, kecuali gelatin. Protein tidak komplet atau protein bermutu rendah adalah protein yang tidak mengandung atau mengandung dalam jumlah kurang satu atau lebih asam amino esensial.
Sumber dari protein berkualitas rendah adalah kacang-kacangan kecuali kacang kedelai. ${ }^{15},{ }^{19}$

Selain asupan protein, asupan zat besi juga meningkat. Zat gizi besi ( $\mathrm{Fe})$ merupakan kelompok mineral yang diperlukan sebagai inti dari hemoglobin, unsur utama sel darah merah. Sebagian peningkatan ini dapat terpenuhi dari cadangan zat besi dan dari zat besi yang diserap oleh saluran cerna. Dalam mengkonsumsi makanan sumber zat besi, selain memperhatikan kuantitas (jumlah zat besi yang terkandung dalam makanan) juga harus memperhatikan kualitasnya yaitu daya serap dan nilai biologisnya tinggi agar dapat memberikan sumbangan zat gizi yang cukup bagi tubuh. $^{20}$

Ada dua jenis zat besi yang terdapat di dalam makanan yaitu: zat besi yang berasal dari heme dan nonheme. Zat besi yang berasal hem merupakan penyusun hemoglobin dan myoglobin. Besi heme terdapat pada makanan hewani, sedangkan besi nonheme umumnya terdapat dalam makanan (kacang-kacangan, buah-buahan, sayursayuran, biji-bijian, dan tofu) dan dairy product (susu, keju dan telur) meskipun dairy product sangat sedikit mengandung besi. ${ }^{19}$

Pada penelitian ini menunjukkan bahwa tidak terdapat perbedaan asupan zat besi antara ibu hamil trimester III anemia dan tidak anemia ( $p=$ 0,75). Berdasarkan pengkajian asupan zat besi diketahui bahwa asupan zat besi ibu hamil anemia lebih banyak berasal dari makanan nabati. Ibu hamil anemia maupun tidak anemia pada penelitian ini mengkonsumsi pangan sumber besi heme dalam frekuensi yang lebih rendah jika dibandingkan dengan frekuensi konsumsi pangan sumber besi non heme. Sebagaimana diketahui bahwa besi heme lebih mudah diserap oleh tubuh daripada besi non heme.

Asam fitat dan faktor lain didalam serat serealia serta asam oksalat didalam sayuran dapat menghambat penyerapan besi. Selain itu, ibu hamil juga sering mengkonsumsi teh setelah makan dengan frekuensi rata-rata dua kali sehari. Beberapa laporan menunjukkan bahwa konsumsi teh berlebih dapat mempengaruhi proses penyerapan zat besi non-heme dalam tubuh. Kandungan tanin dalam teh diketahui membentuk ikatan larut dengan molekul besi non-heme sehingga mencegah penyerapan besi non-heme dalam tubuh. $^{21}$

Konsumsi buah sumber vitamin C seperti pisang, jeruk dan pepaya frekuensinya kurang yang menyebabkan penyerapan zat besi kurang. Vitamin $\mathrm{C}$ sangat membantu penyerapan besi nonheme 
dengan merubah bentuk ferri menjadi ferro. Pada usus halus, zat besi dalam bentuk ferro lebih mudah diabsorpsi. Vitamin $\mathrm{C}$ menghambat pembentukan hemosiderin yang sukar dimobilisasi untuk membebaskan besi bila diperlukan. Absorpsi besi dalam bentuk non heme meningkat empat kali lipat bila ada vitamin C. Dengan demikian resiko anemia defisiensi zat besi bisa dihindari. ${ }^{21}$

Ketidakcukupan jumlah $\mathrm{Fe}$ dalam makanan terjadi karena pola konsumsi makan masyarakat Indonesia masih didominasi sayuran sebagai sumber zat besi yang sulit diserap, sedangkan daging dan bahan pangan hewani sebagai sumber zat besi yang baik (heme iron) jarang dikonsumsi terutama oleh masyarakat pedesaan.

Asam folat merupakan mineral yang cukup penting dalam pembentukan sel darah merah dan sel darah putih dan pematangannya serta berperan dalam metabolisme asam amino. ${ }^{21}$ Sumber asam folat yang baik untuk tubuh adalah daging sayuran hijau, buah-buahan, serealia, dan kacang-kacangan. Pada penelitian ini menunjukkan bahwa tidak terdapat perbedaan bermakna asupan asam folat antara ibu hamil trimester III anemia dan tidak anemia $(p=0,56)$. Berdasarkan pengkajian asupan asam folat diketahui bahwa sumber asupan asam folat ibu hamil lebih banyak berasal dari sayuran. Sayur yang paling sering adalah sayur bayam, daun singkong, dan sayur sop. Frekuensi ibu hamil trimester III mengkonsumsi sayuran hijau rata-rata dikonsumsi 3-4 kali seminggu. Berdasarkan data ini, disimpulkan bahwa pemenuhan jumlah asam folat masih dibawah AKG dikarenakan kebutuhan asam folat yang meningkat tidak diikuti dengan pemenuhan asam folat yang bersumber dari makanan.

Vitamin $\mathrm{B}_{12}$ dibutuhkan untuk mengaktifkan asam folat. Vitamin $B_{12}$ juga dibutuhkan untuk fungsi normal seluruh sel, terutama sel-sel saluran cerna, sumsum tulang dan jaringan syaraf. ${ }^{21}$ Pada penelitian ini menunjukkan bahwa terdapat perbedaan bermakna rerata asupan vitamin $\mathrm{B}_{12}$ antara ibu hamil trimester III anemia dan tidak anemia $(p=0,032)$. Berdasarkan pengkajian data asupan vitamin $B_{12}$ diketahui bahwa ibu hamil trimester III masih kurang mengkonsumsi sumber vitamin $B_{12}$ yaitu hati, daging, susu, telur, dan keju.

Pada penelitian ini didapatkan hasil bahwa kurangnya asupan protein juga berhubungan dengan kurangnya asupan vitamin $\mathrm{B}_{12}$. Penelitian yang dilakukan oleh Burke menyimpulkan bahwa ibu hamil yang mengkonsumsi makanan rendah protein maka juga akan kekurangan vitamin B komplek karena vitamin ini beberapa diantaranya terdapat didalam bahan makanan yang mengandung protein. ${ }^{5}$

Dari hasil analisis data asupan ibu hamil trimester III diperoleh data bahwa tingginya angka kejadian anemia pada ibu hamil trimester III di wilayah Tanggungharjo kabupaten Grobogan bisa disebabkan karena kurangnya asupan vitamin $B_{12}$ yang sering disebut sebagai anemia megaloblastik.

Program pemerintah yang sudah dilaksanakan untuk menurunkan kejadian anemia pada ibu hamil selain dengan peningkatan konsumsi zat gizi terutama zat besi dan asam folat melalui makanan juga dengan pemberian Tablet Tambah Darah (TTD). TTD adalah tablet besi folat yang diberikan pada ibu hamil sebanyak 90 tablet selama kehamilan, dimana setiap tablet mengandung $200 \mathrm{mg}$ Ferro Sulfat atau $60 \mathrm{mg}$ besi elemental dan $0,25 \mathrm{mg}$ asam folat. Akan tetapi kepatuhan dan perilaku ibu hamil untuk mengkonsumsi TTD tidak dianalisis karena dalam pengambilan data sulit untuk mendapatkan jawaban subyek yang valid.

\section{SIMPULAN}

Terdapat perbedaan bermakna asupan protein dan vitamin $\mathrm{B}_{12}$ antara ibu hamil trimester III anemia dan tidak anemia di Puskesmas Tanggungharjo Kabupaten Grobogan. Tidak terdapat perbedaan bermakna asupan zat besi dan asam folat antara ibu hamil anemia dan tidak anemia trimester III di Puskesmas Tanggungharjo Kabupaten Grobogan. Pada penelitian ini dari hasil analisis data asupan yang telah dilakukan, kejadian anemia pada ibu hamil trimester III disebabkan defisiensi vitamin $\mathrm{B}_{12}$ yang sering disebut anemia megaloblastik

\section{SARAN}

Perlu ditingkatkan promosi kesehatan oleh kader dan bidan desa yang tepat dan baik terkait asupan gizi baik dari segi frekuensi, jenis, dan jumlah sesuai usia kehamilan pada ibu hamil serta perlu ditingkatkan sosialisasi pentingnya kepatuhan ibu hamil untuk mengkonsumsi TTD agar dapat mengurangi angka kejadian anemia pada ibu hamil.

\section{DAFTAR PUSTAKA}

1. Riset Kesehatan Dasar. Jakarta: Badan Penelitian Kesehatan Kementrian Kesehatan RI. 2010

2. WHO. 2008. Worldwide Prevalence Of Anaemia 1993-2005: WHO Global Database on Anaemia. 
Edited by Benoist Bruno de, WHO Press, Geneva, p. 7-8

3. Leyla Karaoglu, Erkan Pehlivan. The Prevalence of Nutritional Anemia in Pregnancy in East Anatolian Province, Turkey. BMC Public Health.2007

4. Saifudin. Buku Acuan Nasional Pelayanan Kesehatan Maternal dan Neonatal. Edisi I Cetakan keempat. Jakarta : Yayasan Bina Pustaka Sarwoni Prawirohardja.2006.

5. Arisman, MB. 2004.Gizi Dalam Daur Kehidupan. Jakarta: EGC

6. Merryana A, Bambang W.. Peranan Gizi Dalam Siklus Kehidupan. Jakarta:Kencana, 2012.

7. Riskesdas. 2010. Laporan Nasional 2010.

8. Eko Wijanti Ribut, Rahmaningtyas Indah \& Dewi, W., 2012, Hubungan Pola Makan Ibu Hamil Trisemester III dengan Kejadian Anemia. Vol II No.2.

9. Fadlilah, M, 2009, Hubungan Lama Menstruasi, Status Gizi, Konsumsi Bahan Makanan Peningkat - Penghambat Absorpsi Fe dan Kadar Hemoglobin Pada Karyawati PT. Wyeth Indonesia S1 Undergraduate Esa Unggul Jakarta.

10. Mahenaz Akhtari, Ismail Hassan. Severe Anemia during Late Pregnancy. Hindawi Publishing Corporation Case Reports in Obstetrica and Gynecology Volume 2012, Article ID 485452, 3 pages doi:10.1155/2012/485352

11. Poggi SBH. Postpartum haemorrhage and abnormal puerperium. In: AH Decherney, L Nathan, TM Goodwin, N Laufer (Eds); Current Diagnosis and Treatment, Obstetics and Gynecology, 10 th edn. New York : NY:Mc GrawHill Medical, 2007;477-484

12. Allen LH, de Benoist B, Dary O, Hurrel R. Guidelines on food fortification with micronutrients. Geneva. World Health Organization, 2006; 3-15. Available : http://www.who.int/nutrition/publications/guide_f ood_fortificationmicronutrients.pdf

13. Nasreen H, Ahmed SM, Begum HA, Afsana K. Maternal neonatal and Child health programmers in Bangladesh : review of good practies and lessons learned. Series 32 research monograph. Dhaka : BRAC Center.2010

14. World Health Organitation. Global Nutrition Policy Review: What Does It Take To Scale Up Nutrition Action? Geneva,2013

15. Soekirman, dkk. Ilmu Gizi dan Aplikasinya untuk Keluarga dan Masyarakat. Dirjen Perguruan Tinggi Departemen Pendidikan Nasional.

16. Departemen Gizi dan Kesehatan Masyarakat Fakultas Kesehatan Masyarakat Universitas Indonesia. Jakarta: PT Raja Grafindo Persada. 2007.

17. Henk JB, Saskia de P, Issa S, et al. High Food and the Global Financial Crisis Have Reduced Access to Nutritious Food and Worsened Nutritional
Status and Health. ${ }^{1,2}$ J. Nutr. 140: 153S-161S, 2010

18. Andi Rahmaniar, Nurpudji A.T, Burhanuddin Bahar. The Factors Related to Maternal Chronic Energy Deficiency Intampa Padang, Mamuju Regency West Sulawesi. Media Gizi Masyarakat Indonesia, Vol.2, No.2, Februari 2013 : 98-103

19. Nisreen A. Alwan, Darren C. Greenwood, Nigel A.B. Simpson,Harry J. McArdle, Keith M. Godfrey, and Janet E. Cad. Dietary Iron Intake During Early pregnancy and Birth Outcomes in British in a Cohort of British Women. Human Reproduction, Vol.26, No.4 pp. 911-919, 2011

20. Alexander Krafft, Laura Murray0Kolb, and NilsMilman. Anemia and Iron Deficiency in Pregnancy. Journal of Pregnancy Volume 2012, Articel ID 241869, 1 page doi: $10.1155 / 2012 / 241869$

21. Zijp IM, Korver Sci Nutr. Effect of Tea and Other Dietary Factors on Iron Absorpsion. Crit Rev Food Sci Nutr. 2000 Sep;40(5):371-98. Review

22. Margie Lee Gallagher. Krause's Food and the Nutrition Care Proccess Edition 13: Intake The Nutrients and Their Metabolism. 82-86 